Violetta KORPOROWICZ

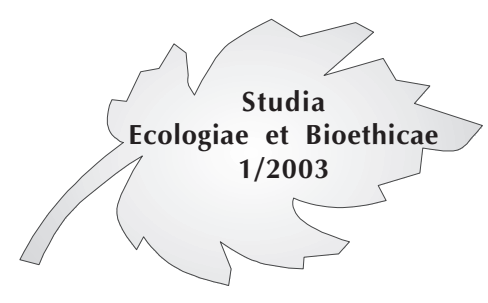

\title{
Ekonomia środowiska - współczesna nauka z tradycjami
}

\begin{abstract}
1. Wstęp
Jednym z najważniejszych problemów obecnych czasów jest degradacja środowiska przyrodniczego. Dotyczy wszystkich wymiarów środowiska i została spowodowana przez człowieka w wyniku prowadzenia działalności bytowej, przemysłowej, komunikacyjnej, handlowej a nawet turystycznej, których założeniem jest zaspokajanie potrzeb społecznych. Degradacja ta wpłynęła na pewne ograniczenia, które pomniejszają przestrzeń życiową a także materialne podstawy bytowania człowieka. Są one związane $\mathrm{z}$ wyczerpywaniem się zasobów nieodnawialnych oraz nadmiernym eksploatowaniem zasobów odnawialnych, zanieczyszczeniami ekosystemów oraz degradowaniem podstawowych komponentów środowiska tzn. powietrza, wody czy gleby.

Ograniczenia przestrzeni życiowej człowieka sprawiły, że przyszłe pokolenia uszczuplone będą miały podstawy gospodarowania w wyniku utraty części zasobów przyrodniczych. Stąd mowa o sprawiedliwości międzypokoleniowej, w której istotne jest, aby kolejne pokolenia miały równy w stosunku do współczesnego, dostęp dóbr przyrody i równą możliwość rozwoju w różnych sferach życia społecznego.

Aby redukować negatywne skutki działalności człowieka zaczęto poszukiwać nowe formy aktywności człowieka w celu przeciwdziałania zagrożeniom wynikającym $\mathrm{z}$ postępu cywilizacyjnego. To spowodowało rozwój nowych dyscyplin wiedzy w tym i ekonomii środowiska, które są niezbędne, aby wskazywać na takie działania, które byłyby racjonalne i przyniosły zamierzony efekt nie tylko $\mathrm{w}$ postaci poprawy stanu środowiska przyrodniczego, ale głównie poprawy dobrobytu społecznego na skutek właśnie poprawy stanu środowiska. Powszechne zrozumienie tej zależności powinno zaowocować w konsekwencji wzrostem gospodarczym i społecznym.
\end{abstract}

\footnotetext{
Katedra Ekologii KES Szkoła Główna Handlowa w Warszawie.
} 
Celem artykułu jest prezentacja stosunkowo nowej dyscypliny naukowej jaką jest ekonomia środowiska oraz zwrócenie uwagi na jej związki z innymi dyscyplinami wiedzy w tym ekologii i ekonomii. Celem artykułu jest też wskazanie na konieczność podejmowania studiów i prac w kierunku rozwoju tych dyscyplin, które mają za zadanie poszukiwanie racjonalności w decyzjach gospodarczych producentów, decyzjach w zakresie konsumpcji poszczególnych jednostek czy decyzjach o charakterze politycznym rządów w stosunku do środowiska przyrodniczego oraz jego jakości.

\section{Tradycje ekonomii środowiska}

Nauką, która dała podstawy ekonomii środowiska jest ekologia. Jest to nauka przyrodnicza, która zajmuje się badaniem stosunków między organizmami lub grupami organizmów żywych a ich środowiskiem. Bada też wzajemne zależności między żywymi organizmami ${ }^{1}$.

Relacje między samymi organizmami a środowiskiem a organizmami żywymi oraz ujemne skutki działań ludzkich uświadamiano sobie od najdawniejszych czasów. Robili to najwybitniejsi myśliciele różnych kultur i epok. Należał do nich m.in. Platon, który w "Uczcie” napisał: „Ziemi szeroka pierś, bezpiecznie stworzeń siedlisko"'2. Grecy odnosili się pozytywnie do przyrody. Było to związane zapewne z ich wierzeniami i religią, $\mathrm{w}$ których świat ożywiony miał patronkę $\mathrm{w}$ postaci Artemidy ${ }^{3}$. W poglądach świętego Franciszka z Asyżu łatwo odszukać można pozytywny stosunek do przyrody. "Święty ten wygłaszał kazania nie tylko dla ludzi, ale i do zwierząt i roślin. Wskazywał też na swój braterski stosunek do wszystkich istot żywych ${ }^{4}$.

Za twórcę ekologii uważa się Ernsta Haeckela, który po raz pierwszy zaproponował ten termin ${ }^{5}$. Było to w $1869 \mathrm{r}$. Zaczął on bowiem badać relacje między organizmami a otaczającym ich światem zewnętrznym. Sam

1 Pojęcie „ekologia” zaczerpnięte zostało od greckiego słowa „oikos”, przez które rozumie się „dom, domostwo, miejsce zamieszkania, środowisko"1. Jednak starogrecki słownik, jako jedyny podaje inne znaczenie słowa „oikos”, tzn. wspólnota. Grecy zatem w tym pojęciu podnosili wątek nie tylko fizycznego wymiaru środowiska, ale też społecznego, bez którego człowiek nie może żyć i rozwijać się.

2 Platon, Uczta. Przełożył, wstępem, objaśnieniami i ilustracjami opatrzył W. Witwicki. PWN, Warszawa 1988, s. 61.

3 E. Hargrove, Foundations of environmental ethics. Englewood Cliffs, Prentice Hall, New Jersey 1988, s. 16-18.

4 V. Korporowicz, Ekologiczne uwarunkowania zdrowia. Oficyna Wydawnicza SGH, Warszawa 2000 , s. 9.

5 B. SPOOnER, Ecology in development: a rationale for three-dimensional policy. The United Nations University, Tokyo 1984, s. V. 
E. Haeckel badał zwierzęta morskie. W swoich pracach poszerzył teorię Darwina o oddziaływaniach na siebie gatunków w walce o byt. Ponieważ jednak w drugiej połowie XIX w. nie potrafiono jeszcze budować syntetycznych hipotez na temat wzajemnych stosunków między gatunkami i wzajemnego oddziaływania na siebie roślin i zwierząt, powstawały na ogół wyraźnie oddzielone od siebie dziedziny: ekologia roślin i zwierząt. Dopiero postęp wiedzy w pierwszej połowie XX wieku spowodował przybliżenie obu tych kierunków i powstanie ekologii ogólnej ${ }^{6}$. Nauka ta zajmuje się badaniem nie tylko relacji między organizmami żywymi a środowiskiem czy granic wytrzymałości populacji na różne czynniki biotyczne i abiotyczne, ale także społecznymi warunkami życia ${ }^{7}$.

Na rozwój ekologii ogromny wpływ miała grupa uczonych z Wydziału Socjologii i Antropologii Uniwersytetu w Chicago, badająca urbanizację i miejskie sposoby życia. Właśnie tu powstał nowy kierunek ekologii, nazwany ekologią człowieka (human ecology). „Ów wydział nie był jednak sam przez się szkołą naukową, ponieważ skupiał uczonych o różnych orientacjach, którzy potrafili wprawdzie zgodnie współpracować w ramach uniwersytetu oraz innych instytucji [...], ale nie reprezentowali żadnej głębszej naukowej jedności"8. Do historii myśli społecznej przeszli pod nazwa Szkoły Chicagowskiej. Pracowali w latach 1915-1930. Zainteresowani byli obserwacją zachowań ludzkich w konkretnym miejscu i środowisku. Przy czym było to środowiska miejskie ${ }^{9}$.

6 V. Korporowicz, Ekologiczne..., op. cit., s. 10.

7 Istnieje wiele nieporozumień wokół terminu „ekologia”, który powszechnie mylony jest z ochroną przyrody. Wydaje się, że tkwi w tym dwojakiego rodzaju nieporozumienie. Po pierwsze, ta część ekologii, która stanowi podstawę nauki o ochronie przyrody nazwana jest sozologią. Sozologia - od sodzo (sodro) - oznacza po starogrecku chronić, a po nowogrecku ratować, ocalać, wybawiać. Termin ten wprowadził polski uczony W. Goetel. Sozologia jest to nauka, która dąży do rozpoznania trwałości zasobów przyrody oraz zajmuje się doraźnymi skutkami i następstwami przemian w ekosystemach. Po drugie, ochrona przyrody to nie jest nauka, co systemem działania. Pojęciem tym określa się więc działania, które mają na celu zachowanie naturalnych warunków przyrodniczych poszczególnych terenów bądź też pojedynczych obiektów. Gdybyśmy o ochronie przyrody chcieli mówić jako o nauce, to należałoby użyć albo pojęcia sozologia albo „nauka o ochronie przyrody”. Jednak należy dodać, że termin sozologia nie został zaakceptowany przez środowiska naukowe i nie jest on powszechnie używany, to powoduje zamienne, często zupełnie nieprawidłowe stosowanie pojęcia „ekologia” i „ochrona przyrody”. Kolejnym nieporozumieniem terminologicznym jest używanie terminu ochrona przyrody z pojęciem ochrona środowiska. Pojęcia te są traktowane jako synonimy, chociaż warto pamiętać, że ochrona środowiska obejmuje swym zakresem nie tylko środowisko przyrodnicze, lecz także społeczne i psychiczne. Zatem ochrona przyrody są to działania czy system działań na rzecz racjonalnej gospodarki zasobami przyrody, obejmujące też kształtowanie nowych ekosystemów lub rekultywację zdegradowanego środowiska przyrodniczego.

8 J. SzACKI, Historia myśli socjologicznej. Cz. 2. PWN, Warszawa 1981, s. 645.

9 J. Turner, S. Turner, Socjologia amerykańska w poszukiwaniu tożsamości. IfiS PAN, Warszawa 1993, s. 44-46. 
Kolejnymi krokami w rozwoju ekologii było zbudowanie koncepcji ekosystemu, którego właściwości wynikają z jego wzajemnych powiązań biotycznych i abiotycznych. Współzależności składowych tworzą i integrują całościowy system przyrodniczy, na który składają się elementy fizyczne, chemiczne i biologiczne ${ }^{10}$. Pełny układ przyrodniczy tworzą wszystkie populacje zamieszkujące określone środowisko, które powiązane są ze sobą poprzez procesy wymiany materii i energii ${ }^{11}$. Przykładem pełnego układu przyrodniczego jest konkretny las, staw, łąka lub ich fragmenty ${ }^{12}$. Jednak wraz z rozwojem cywilizacyjnym ekosystemy traca cechy układów naturalnych i stają się ekosystemami zmodyfikowanymi przez człowieka. Tworzone są nowe ekosystemy np. miejskie czy rolnicze. Jeżeli jednak przekształcenia idą zbyt daleko, zakłócane zostają funkcje ekologiczne co w konsekwencji może dać z czasem nieodwracalne zmiany np. może nastąpić utrata najcenniejszych składników odżywczych $\mathrm{w}$ glebie czy pustynnienie obszarów rolniczych ${ }^{13}$.

Następnym elementem $\mathrm{w}$ rozwoju ekologii oraz wiedzy na temat wpływu działań człowieka na przyrodę był raport U Thanta „Tylko jedna ziemia" oraz raporty dla Klubu Rzymskiego przyczyniły się do rozwoju ekologii oraz powszechnego postrzegania związków między działalnością gospodarczą człowieka a degradacją przyrody. Pierwszy z raportów, "Granice wzrostu", pomimo powszechnie krytykowanych błędów metodologicznych, wstrząsnął światem intelektualnym. W rezultacie powstały nowe kierunki badawcze, np. filozofia ekologiczna, ekologia kulturowa czy etyka ekologiczna ${ }^{14}$.

Konsekwencją rozwoju wiedzy na temat relacji człowiek - środowisko było wykształcenie się nowego kierunku ekologii nazwany „ekologią głęboką". Oznacza on taki sposób myślenia o świecie, przyrodzie i o człowieku, który zakłada ich zasadniczą jedność ${ }^{15}$. Ważną cechą ekologii głębokiej jest uznanie wszystkich form życia za tak samo istotne. Neguje się zarazem jakąkolwiek dominację człowieka nad naturą. Cała przyroda, wszystko co żyje ma równe prawo do istnienia. Człowiek tym sa-

10 G. Moore, A. Magaldi, J. Gray, The legal environment of business: a contextual approach. South-Western Publ., Cincinnati 1987, s. 662.

11 E. Odum, Basic ecology. Saunders College Publ., Philadelphia 1983, s. 3.

12 J. Semkow, Ekonomia a ekologia. PWN, Warszawa 1980, s. 46.

13 A. Woś, Ekonomika odnawialnych zasobów naturalnych. SGH, Warszawa 1993, s. 23.

14 Etyka ekologiczna jest ważnym nurtem myśli humanistycznej, gdyż uznaje nie tylko to, co jest korzystne dla całości świata żywego. Racjonalny kodeks postępowania moralnego nie może uwzględniać jedynie wzajemnych stosunków międzyludzkich, ale też stosunki między człowiekiem a przyrodą.

15 A. NAESS, Samourzeczywistnienie - ekologiczne podejście do istnienia w naszym świecie. (w:) Zielona antologia. Wybór i oprac. A.Korbel, J.Tyrlik. Politechnika Śląska, Gliwice 1989, s. 18-19. 
mym jest tylko jednym $\mathrm{z}$ wielu elementów biosfery ${ }^{16}$. Ekolodzy głębocy postrzegają świat holistycznie, tzn. całościowo, a wszystkim składnikom przyrody nadają taka samą wagę. Dlatego człowiekowi nie przypisuje się jakiejś szczególnej, uprzywilejowanej roli czy miejsca wśród innych bytów. Przeciwnie podkreśla się, że to człowiek nie może istnieć bez otaczającego go świata roślin i zwierzą ${ }^{17}$. Postulują oni swoistą biocenotyczną etykę, będącą zaprzeczeniem dominującej $\mathrm{w}$ kręgu kultury zachodniej etyki antropocentrycznej. Oznacza to, że każdej formie życia przypisuje się prawo do istnienia i rozwoju, które może być sprzeczne z doraźnymi interesami człowieka. Cywilizacja przemysłowa jako tzw. stary paradygmat daje człowiekowi szczególne prawa, nakazując wręcz podporządkowanie sobie natury i przekształcenie jej w dogodną formę dla człowieka. Swoista filozofia ekologiczna przechodzi od ilościowego do jakościowego pojmowania wzrostu gospodarczego, a głównie do kategorii jakości życia. Zasadniczym problemem staje się tutaj wspótistnienie, które nie narusza równowagi ekologicznej ${ }^{18}$. A człowiek jest tylko jednym z elementów świata przyrody i dlatego musi respektować prawa natury.

Idee ekologów głębokich uznawane są jako zbyt dogmatyczne. Przyjęcie zasad tej filozofii wymusza pogląd, że ludzkie potrzeby i cele nie powinny być $\mathrm{w}$ żaden sposób uprzywilejowane $\mathrm{w}$ porównaniu $\mathrm{z}$ potrzebami innych istot żywych ${ }^{19}$.

Są oni również krytykowani za brak odniesień do rzeczywistości i niekonsekwentny stosunek do własnych idei. Przedstawiciele biocentryzmu np. krytykują dotychczasowe rozumienie zagadnień środowiska. Sami jednak nie wypracowali własnych rozwiązań. Korzystają raczej z istniejących wzorców. Proponują zatem nadal cząstkowe działania, tzn. ochronę powietrza, surowców, wody, ginących gatunków. Tym samym nie wprowadzają żadnej zmiany w swojej filozofii postępowania w stosunku do tradycyjnego podejścia. Innym elementem krytyki założeń ekologii głębokiej jest jej niekonsekwentny stosunek do człowieka. Głównym filarem tej filozofii jest równe traktowanie wszystkich istnień żywych. Znaczy to, że człowiek jako istota żywa powinien być jednakowo postrzegany. Tymczasem biocentryści wykluczają człowieka z natury, traktując go inaczej niż inne byty, jako gatunek najbardziej szkodliwy i niebezpieczny. Skoro człowiek jest częścią przyrody, to jego postępowanie powinno być traktowane jako naturalne, a nie wyłączone poza nawias, jak postulują to ekolodzy głębocy ${ }^{20}$.

16 Z. MeLosik, Postmodernistyczne kontrowersje wokót edukacji. Edytor, Toruń 1995, s. 100-101.

17 J. Smolicz, Man's coercion of nature: a historical and sociologocal pespective. (w:) Nature, science and values. Red N. Castillo. Santo Tomas University Press, Manila 1990, s. 275-280.

18 F. Capra, Punkt zwrotny. Tłum. E. Woydyłło. Przedmowa A. Wyka. PIW, Warszawa 1987, s. $363-418$

19 Z. MelosiK, op.cit., s. 107, 110.

20 Ibidem, s. 111. 
Ekologia głęboka mimo licznych wad i sprzeczności zaproponowała nowe spojrzenie na rolę i stosunek człowieka do przyrody. Dla przedstawicieli ekologii głębokiej zerwanie $\mathrm{z}$ antropocentryzmem nie oznacza jednak deprecjacji jednostki ludzkiej, przeciwnie - uważają oni, że dążą do tego, by w życiu społecznym stwarzać warunki wszechstronnego rozwoju człowieka. Zgodnie z tą filozofią, rozwój jest możliwy wtedy, gdy „Każda osoba, która nie jest zagrożona w ważnych dla siebie wartościach, spontanicznie dąży do rozszerzenia swej wiedzy, pogłębienia swojego rozumienia świata i zrealizowania swoich możliwości"21. Ekolodzy głębocy uważają również, że jeżeli nie zmienią rabunkowego stosunku człowieka do natury to przynajmniej zwrócą uwagę na fakt jej nadmiernej i często niepotrzebnej degradacji.

Podsumowując ten fragment artykułu należy stwierdzić, że problemy degradacji środowiska nie są efektem niedoskonałości techniki, lecz konsumpcyjnego systemu wartości w społeczeństwach masowych. Również błędne decyzje podejmowane w celu źle zrozumiałego wzrostu gospodarczego spowodowały, że poszczególne zasoby były zbyt długo traktowane jako dobra wolne i nadmiernie eksploatowane. Taki stosunek do środowiska doprowadził do jego nieuzasadnionej degradacji ${ }^{22}$.

\section{Ekonomia środowiska jako nauka}

Do nauk, które podejmują problemy relacji środowisko-człowiek poza naukami przyrodniczymi zaliczyć należy również te z zakresu nauk społecznych a szczególnie ekonomii, która badania ludzkie zachowania, jako stosunek między danymi celami i ograniczonymi środkami o alternatywnych zastosowaniach $\mathrm{w}$ tym między innymi racjonalne działania człowie$\mathrm{ka}$ w środowisku ${ }^{23}$. Na skrzyżowaniu tych nauk powstała ekonomia środowiska, nauka interdyscyplinarna czerpiąca swe korzenie z ekologii i ekonomii. Jest to stosunkowo nowa dyscyplina, gdyż licząca sobie około pięćdziesiąt lat. Potrzeba łączenia zasad wypracowanych na gruncie ekologii i ekonomii oraz stosowania praw opisywanych przez obie dyscypliny wynika z faktu określenia odpowiedzialności za zanieczyszczenia powstałe w wyniku przerzucania negatywnych skutków działalności gospodarczej na innych członków społeczeństwa. Fakt ten uszczupla trwałość zasobów przyrodniczych, co w konsekwencji ogranicza rozwój ekono-

21 „Miesięcznik Trochę Inny” nr 0/1/1989.

22 V. Korporowicz, Zdrowie społeczne jako element ekorozwoju. Mechanizmy i uwarunkowania ekorozwoju. II Międzynarodowa Interdyscyplinarna Konferencja Naukowa. Politechnika Białostocka. Katedra Zarządzania Środowiskiem i Turystyką, Białystok 1998, s. 178.

23 M. Blaug, Teoria ekonomii. Wydawnictwo Naukowe PWN, Warszawa 1994, s. 30. 
miczny i społeczny. To wymusza zastosowanie działań, które skłoniłby uczestników rynku do zrealizowania wspólnego wysiłku, jakim jest ochrona środowiska przyrodniczego.

Ekonomia środowiska wykorzystuje paradygmat ekonomii neoklasycznej, gdzie podstawowym założeniem metodologicznym jest zarówno model człowieka racjonalnego i jednocześnie egoistycznego, który bazuje na kartezjańskim przeświadczeniu o nieomylności nauki i metody naukowej oraz tego, że człowiek w oparciu o naukowe metody postępuje racjonalnie. Mowa tu o homo oeconomicus czyli jednostce, która podejmuje racjonalne decyzje $\mathrm{w}$ celu maksymalizacji indywidualnej i społecznej satysfakcji ${ }^{24}$.

Kolejnym założeniem ekonomii neoklasycznej jest przekonanie, że rynek jest najskuteczniejszym oraz najefektywniejszym instrumentem regulującym popyt i podaż na poszczególne dobra, co spowodować powinno prawidłową alokację zasobów. Rynek i gospodarka rynkowa doprowadzają w tym ujęciu do skutków społecznie oczekiwanych. Jest to działanie "niewidzialnej ręki” rynku, które reguluje wszelkie procesy rozwojowe $\mathrm{w}$ gospodarce wolnorynkowej.

Oba te aksjomaty ekonomii neoklasycznej wykorzystuje a następnie poddaje krytyce ekonomia środowiska $\mathrm{w}$ celu odszukania zależności między jakością środowiska a funkcjonowaniem systemu gospodarczego. Chodzi tu o występowanie efektów zewnętrznych oraz o ograniczoność zasobów przyrodniczych, które rozpatrywane są przez pryzmat niezawodności rynku oraz o racjonalne decyzje z punktu widzenia gospodarczych poczynań człowieka.

W gospodarce rynkowej istnieje przekonanie, że właśnie rynek jest najskuteczniejszym narzędziem osiągania tego co społecznie pożądane. Jednak taki typ gospodarki wymuszać może błędną alokację zasobów, spowodowaną efektami zewnętrznymi, które odpowiedzialne są za narastanie problemów ekologicznych. Efekt zewnętrzny ma miejsce wtedy, gdy producenci przerzucają na osoby trzecie nie będące ani konsumentem ani producentem skutków swojej produkcji w postaci zanieczyszczeń. W tym przypadku właśnie rynki zawodzą, ponieważ jakość środowiska nie podlega wymianie rynkowej. A sam rynek nie może doprowadzić do efektywnej alokacji zasobów przyrody. Efektywność może być osiągnięta poprzez pewne formy interwencji państwa $\mathrm{w}$ postaci stosowanych przepisów, w tym szczególnie instrumentów ekonomicznych.

Również działania homo economicus w systemie gospodarki rynkowej nie są z punktu widzenia środowiska racjonalne, gdyż tenże "człowiek ekonomiczny" działając gospodarnie, aby utrzymać się na rynku ogranicza swoje koszty produkcji. Chodzi tu o zanieczyszczenia, których

24 A. Woś, op. cit., s. 63. 
ani nie redukuje ani ich nie utylizuje tylko bezpośrednio emituje do środowiska, zanieczyszczając go. Przez co dba o wzrost swoich korzyści kosztem degradacji przyrody i innych osób, które nie muszą być uczestnikami wymiany.

Ekonomia środowiska podejmuje wiele zagadnień z pogranicza ekonomii i ekologii. Wśród najważniejszych problemów zaliczyć należy wykorzystywanie zasobów przyrody do celów gospodarczych. W bloku tym uwaga skupiona jest na wyjaśnianiu, jakie gospodarcze przyczyny tkwią u podstaw zagadnień ochrony środowiska i jego zasobów a także jakie są konsekwencje ekonomiczne degradacji przyrody ${ }^{25}$. Te elementy związane są z analizą funkcjonowania rynków w kontekście ochrony środowiska oraz rozważaniami na temat sposobów korygowania negatywnych działań rynków, które ekonomiści nazywają defektami rynku. Szczególny nacisk położony jest tu na błędną alokację zasobów, która spowodowana jest efektami zewnętrznymi rozumianymi jako niechciane skutki ekologiczne działalności gospodarczej człowieka. Ten nurt ekonomii środowiska określany bywa jako ekonomia efektów zewnętrznych.

$\mathrm{W}$ ramach tej części dyscypliny podejmowane są zagadnienia korygowania ujemnych efektów zewnętrznych poprzez internalizację kosztów, które ponieść powinni sprawcy zanieczyszczeń. Instrumentem korygowania tych ujemnych efektów jest podatek, który aby przyniósł pożądany efekt powinien być równy wartości krańcowego efektu zewnętrznego. Tego typu podatek nazywany jest podatkiem Pigou. Nazwę wziął od nazwiska Artura Pigou, który pierwszy zaproponował stosowanie tego typu instrumentu, jako element realizowanej polityki państwa $\mathrm{w}$ celu skorygowania społecznie niepożądanych skutków spowodowanych ujemnymi efektami zewnętrznymi ${ }^{26}$. Optymalna wysokość podatku Pigou określona jest od każdej wyemitowanej jednostki produkcji, na poziomie wartości krańcowego kosztu oczyszczania. Jest to punkt społecznego optimum. Co oznacza, że każdy zakład będzie zmniejszał swoją emisję dotąd, dopóki podatek będzie przewyższał krańcowe koszty oczyszczania. Do czasu kiedy koszty oczyszczania przewyższają wysokość podatku opłaca się go opłacać. W przeciwnym wypadku, kiedy koszt oczyszczenia zanieczyszczeń jest niższy niż podatek to zakład będzie zainteresowany oczyszczaniem bardziej niż płaceniem podatku ${ }^{27}$. Jednak wykorzystywanie podatku, jako ekonomiczny instrument ochrony środowiska na jego zbyt wysokim poziomie może doprowadzić do

25 H. Folmer, L. Gabel, H. H. Opschoor, Ekonomia środowiska i zasobów naturalnych. Wprowadzenie. (w:) H. Folmer, L. GABel, H. H. Opschoor, Ekonomia środowiska i zasobów naturalnych. Wyd. Krupski, Warszawa 1996, s. 13.

26 K. Lofgren, Środowisko i zasoby naturalne w perspektywie ekonomicznej. (w:) H. Folmer, L. Gabel. H. OpschoOr, Ekonomia..., op. cit., s. 33. 
ograniczenia możliwości produkcyjnych zakładu, a to do wyeliminowania takiej jednostki z rynku. Bankructwo zakładu z punktu widzenia polityki ekonomicznej rzadko kiedy jest korzystnym rozwiązaniem.

Kolejny nurt zainteresowań ekonomii środowiska koncentruje się na wykorzystaniu i ochronie zasobów przyrody, które dzielimy na nieodnawialne i odnawialne. Do pierwszych zaliczamy różnego typu kopaliny tzn. węgiel, siarkę, rudy, ropę naftową, gaz, sól. Cechą charakterystyczną tych zasobów jest to, że w wydobywane są $\mathrm{z}$ wnętrza ziemi, a złoże, z którego korzystano nie odnawia się. Wyeksploatowane złoże traci bezpowrotnie swoją wartość. Natomiast zasoby odnawialne mogą być ciągłym źródłem ich pozyskiwania pod warunkiem, że wykorzystywane są racjonalnie. Wszystkie zasoby naturalne poza kopalinami są odnawialne. Związane jest to $\mathrm{z}$ procesem ich odnowy i $\mathrm{z}$ istnieniem praw przyrody. Przykładem zasobów odnawialnych jest woda płynąca, lasy, świat zwierzęcy i roślinny, energia słoneczna, wiatru ${ }^{28}$. W przypadku zasobów zainteresowania ekonomii środowiska dotyczą środowiska jako dostawcy surowców niezbędnych do funkcjonowania gospodarki przy czym w założeniach tej dyscypliny, gospodarka ma nadrzędną funkcję w stosunku do środowiska ${ }^{29}$.

W przypadku zasobów szczególnie nieodnawialnych przedstawiciele ekonomii środowiska wychodzą z założenia, że uda się je zastąpić w wyniku wprowadzenia surowców o charakterze substytucyjnym, szczególnie jeżeli weźmie się pod uwagę istniejący postęp techniczny. Substytucja może też oznaczać zastępowanie i wprowadzanie nowych technologii, które ograniczają zużycie surowców. Efektem postępu technicznego mogą być też nowe produkty, które eliminują potrzebę korzystania $z$ tych zasobów, które są naturalnie ograniczone w przyrodzie.

Ekonomia środowiska podejmuje zatem zagadnienia przyczyn jakie leżą u podstaw ochrony środowiska przyrodniczego i jego zasobów i ekonomicznych konsekwencji degradacji środowiska. Następnymi zagadnieniami, które bada ta dyscyplina są metody wyceny jakości środowiska. Wyceny te potrzebne są $\mathrm{w}$ zastosowaniu rachunku ekonomicznego, który niezbędny jest do analizy kosztów i korzyści zamierzeń, które wywierają wpływ na stan środowiska lub przy ocenie strat $\mathrm{w}$ zasobach. Oceny te niezbędne są przy oszacowaniu efektywności działalności gospodarczej.

Wyceny środowiska, jako dobra nierynkowego prowadzone są metodami bezpośrednimi i pośrednimi. W pierwszej grupie znajdują się me-

Ibidem, s.34.

28 A. Woś, op. cit., s. 8-9.

29 P. JEżowsKi, Ekonomia środowiska a ekonomia ekologiczna. (w:) Ochrona środowiska a ekorozwój. Oficyna Wydawnicza SGH, Warszawa 2000, s. 11. 
tody, w których używa się danych hipotetycznych uzyskanych w wywiadach z poszczególnymi konsumentami. Potencjalni konsumenci wypowiadają się na temat cen, jakie byliby skłonni zapłacić za poszczególne komponenty środowiska. W metodach pośrednich wartość środowiska oceniana jest na podstawie cen dóbr i usług rynkowych np. ceny ziemi lub mieszkań, które mogą mieć inna cenę i zależeć od tego, jaki jest stan środowiska, w którym są zlokalizowane. Im korzystniejszy stan środowiska tym wyższy może być poziom cen tych dóbr.

Wyceniając środowisko trzeba mieć zawsze na uwadze fakt, że wyceny te robione są one różnymi metodami. Mają wiele wad i ograniczeń. Jednak dzięki nim można uzyskać przybliżoną wiedzę zarówno na temat wartości środowiska jak i kosztów, które ponosi społeczeństwo w następstwie degradacji środowiska przyrodniczego.

\section{Podsumowanie}

Stały wzrost znaczenia problemów degradacji środowiska przyrodniczego oraz jego ochrony spowodowany jest między innymi ograniczaniem efektywności gospodarowania. To wymusza potrzebę spojrzenia się na procesy gospodarcze $\mathrm{z}$ uwzględnieniem dorobku takich dyscyplin, które mówią jak należy gospodarować $w$ warunkach ograniczonych zasobów przyrodniczych. Do tych dyscyplin należy bez wątpienia ekonomia środowiska.

Nauka ta wskazuje na metody i instrumenty ekonomiczne jakie można stosować w praktyce gospodarczej niezbędne w ochronie środowiska. Podejmuje też problemy sposobów badania ekonomicznych implikacji polityki środowiskowej. Tym samym ekonomia środowiska, która wyrosła z neoklasycznego nurtu ekonomii, który przyjmuje rynek jako niezawodny mechanizm regulacji ekonomicznej udowadnia, że niewidzialna ręka rynku w przypadku ochrony środowiska jest zawodna. Dlatego właśnie należy stosować różnego typu instrumenty szczególnie regulacji pośredniej (w tym instrumenty ekonomiczne takie jak podatki), które wspierają działania na rzecz ograniczania degradacji środowiska.

Warto też dodać, że rozpoznanie założeń metodologicznych tej nauki sprzyja rozwojowi nie tylko samej dyscypliny jako takiej, ale przede wszystkim jest wskazaniem na jej aplikacyjny wymiar. Praktyczne zastosowanie zasad wypracowanych przez ekonomię środowiska powinno być wykorzystywane przez wszystkich uczestników życia gospodarczego i to poczynając od konsumentów kończąc na producentach i rządach w celu nie tylko zachowania istniejących zasobów przyrody, ale przede wszystkim, aby zadbać o możliwość rozwoju kolejnym pokoleniom. 


\section{Bibliografia}

Blaug M., 1994 - Teoria ekonomii. Wydawnictwo Naukowe PWN, Warszawa.

CAPRA F., 1987 - Punkt zwrotny. Tłum. E. Woydyłło. Przedmowa A. Wyka. PIW, Warszawa.

Folmer H., Gabel L., Opschoor H., 1996 - Ekonomia środowiska i zasobów naturalnych. Wyd. Krupski, Warszawa.

Hargrove E., 1988 - Foundations of environmental ethics. Englewood Cliffs, Prentice Hall, New Jersey.

JEżowski P., 2000 - Ekonomia środowiska a ekonomia ekologiczna. (w:) Ochrona środowiska a ekorozwój. Oficyna wydawnicza SGH, Warszawa.

Korporowicz V., 2000 - Ekologiczne uwarunkowania zdrowia. Oficyna Wydawnicza SGH, Warszawa.

Korporowicz V., 1998 - Zdrowie społeczne jako element ekorozwoju. Mechanizmy i uwarunkowania ekorozwoju. II Międzynarodowa Interdyscyplinarna Konferencja Naukowa. Politechnika Białostocka. Katedra Zarządzania Środowiskiem i Turystyką, Białystok.

Moore G., Magaldi A., Gray J., 1989 - The legal environment of business: a contextual approach.

NAEss A., Samourzeczywistnienie - ekologiczne podejście do istnienia w naszym świecie. (w:) Zielona antologia. Wybór i oprac. A.Korbel, J.TYrLIK. Politechnika Śląska, Gliwice . SouthWestern Publ., Cincinnati 1987.

Odum E., 1983 - Basic ecology. Saunders College Publ., Philadelphia.

Platon, 1988 - Uczta. Przełożył, wstępem, objaśnieniami i ilustracjami opatrzył W. Witwicki. PWN.

SEMкоw J., 1980 - Ekonomia a ekologia. PWN, Warszawa.

SMolicz J., 1990 - Man's coercion of nature: a historical and sociologocal pespective. (w:) Nature, science and values. Red N. Castillo. Santo Tomas University Press, Manila.

SPOONER B., 1984 - Ecology in development: a rationale for three-dimensional policy. The United Nations University, Tokyo.

SzAcKi J., 1981 - Historia myśli socjologicznej. Cz. 2. PWN, Warszawa.

TURNER J., TURNER S., 1993 - Socjologia amerykańska w poszukiwaniu tożsamości. IfiS PAN, Warszawa.

Woś A., 1993 - Ekonomika odnawialnych zasobów naturalnych. SGH, Warszawa.

\section{Economy of environment - current science with traditions}

\section{SUMMARY}

The fact that problems of environmental degradation and its protection are getting more important is caused among others by limitation in management efficiency. It force us to look at economic processes with consideration of output of such disciplines that say how one shall manage in situation of limited natural resources. This discipline is without any doubts environmental protection.

This science indicates methods and economic instruments that can be applied in economic practice necessary in environmental protection. It deals also 
with problems related to economic researches of implications of environmental policy. At the same environmental economics that results from neo-classical trend of economics looking at the market as unfailing mechanism of economic regulation proves that invisible hand of market fails in case of environmental protection. That's why we shall apply different types of instruments especially these related to indirect regulation (including such economic instruments as taxes) that support actions related to limitation of environmental degradation.

It's worth also to add that recognition of methodological premises of this science supports not only development of this discipline but first of all it shows her applicable character. Practical usage of rules prepared by environmental economics shall be used by all participants of economic life beginning with consumers and finishing with producers and governing in order to keep not only current natural resources but first of all to take care after possible development of next generations. 